\title{
Research for Training System and Paths of Professional Degree Postgraduate's Engineering Innovation Ability
}

\author{
Shoukui $\mathrm{He}^{1, \mathrm{a}}$ and Yugang Jian ${ }^{2, \mathrm{~b}}$ \\ ${ }^{1}$ School of Economics and Management, Chongqing Jiaotong University, Chongqing 400074 \\ ${ }^{2}$ Department of Management, Chongqing Institute of Engineering, Chongqing 400056 \\ ahsk0657@cqjtu.edu.cn, b411078251@qq.com
}

Keywords: Professional degree postgraduate; Innovation ability; Training system; Safeguard
mechanism

\begin{abstract}
Training innovative postgraduate with professional degree is the urgent requirement of national implementation of innovation-driven development strategy. Comparing with academic degree graduate students, they have no obvious advantage in engineering-innovation ability. Instead, they are weak in basic knowledge and R \& D ability. In view of this, put forward the system and basic conditions of building engineering innovation ability of professional degree postgraduate, and analyze the influencing factors and formation mechanism of innovation ability. We establish the "three-body", "three-stage" innovation training system which is based on the innovation ability. Establish the safeguard mechanism for supporting policies, organization and talents, financial resources and quality supervision of training-innovation in degree research project.
\end{abstract}

\section{Introduction}

Implementation of innovation-driven development strategy needs a large number of top creative talents and a high level of innovative ability of application talents. So in the Eighteenth National Congress of the CPC which made a clear request for the implementation of innovation-driven development strategy and cultivate innovative talents, and the State Council "on deepening the reform of Higher Education Innovation and Entrepreneurship The (SCS [2015] 36) opinions "to further clarify the Higher Education Reform in the general direction of the implementation of innovation and entrepreneurship. Graduate education is the important way to cultivate the country's top talents, many countries have made the postgraduate education as the strategic choice to establish innovative country and improve high-technology international influence. In 2009, China began to recruit graduate professional degree, and in 2015 the number of professional degree postgraduate students have accounted for more than 50 percent of the total size. Establish professional degree postgraduate Creative Ability system is worthy of discussion topics. Objective to explore professional degree postgraduate training rules, innovative talent training mode, to adapt to the requirements of the national development strategy of innovation and entrepreneurship, training senior innovation and technology development-oriented graduate professional degree graduate education is the main theme of our future development. Professional degree graduate engineering innovation ability is the use of accumulated knowledge and experience, through specific training, then form engineering and project management of new knowledge, new ideas, new methods and new achievements. In this paper, based on investigation and analysis of relevant research results and research degree graduate student innovation ability training system and safeguard mechanism.

\section{Current Situations and Problems Analysis}

In recent years, the urgency of training innovative professional degree postgraduate students in China have reached a consensus, in the institutions of higher learning and enterprises who are actively exploring and practicing its own unique mode of innovative talents cultivation, such as co-operative, order cultivation, the way of university-enterprise cooperation. According to related theoretical researches divided professional degree postgraduate innovation ability into three levels: 
One is postgraduate self-learning ability and awareness of the cutting edge of technology; The second is engineering innovation ability and complex technical management ability; The third is the ability to adapt to the organization and the ability to solve complex problems, etc. From the front view, we can come to the conclusion that the problems of the professional degree graduate education are heavy theory, light practice, heavy curricular, extracurricular light. And students lack the necessary practical training because that the relative scarcity of resources practice, and no innovative training system. Innovative training system so lag in postgraduate education and professional facing narrow that limit students' creative thinking and reduce innovation space and opportunities for graduate students learn from each other. Degree of Tutors practical ability and business mentors absence affected the training quality of engineering innovation capabilities. Proposed the building of science and technology innovation platform, cultivate innovative teachers, graduate students and research collaborative innovation. Practice ability and the enterprise professional degree tutors absence affect the engineering quality of the cultivation of innovative ability. Put forward to build a scientific and technological innovation platform, cultivate innovative teachers, production-study-research cooperation training graduate students innovation ability.

In 2013, "the Ministry of Education, the National Development and Reform Commission, Ministry of Finance Opinions on Deepening the Reform of Graduate Education" (Teaching and Research 2013) on the 1st paper noted Postgraduate Education objectives that cultivate high-level technical application ability, practical and innovative ability and high level management skills. It emphasizes to train the postgraduate with high level application ability and engineering practice and innovation ability. Construction of the key technology needs of the enterprise industry as the guide, to the engineering practice and innovation ability training as the key of the professional degree graduate students to cultivate innovative talents unique training mode. Construction of Postgraduate Education Innovative mechanisms, including establishing the concept of compound talents training, diversity of training methods and the establishment of Cooperative Training Management Innovation System. All colleges and universities actively promote the implementation of innovation-oriented professional degree graduate education programs and personnel training mode reform. Yangzhen proposed that "five in one" full-time professional degree graduate training mode which had elaborated innovative postgraduate training base for professional degree graduate students' innovative ability effect [1]; Zhang Yun from the aspects of the orientation of the talents, the curriculum system and the training of innovative quality control proposed professional degree graduate training mode reform direction [2]; Xu Xiaolong proposed professional degree graduate students' innovation ability "spiral lifting type" training mode and relevant suggestions in the construction of the supporting system [3].

In the western developed countries, the establishment of the industry organization and backbone enterprises participate in the postgraduate student innovation ability training system. The curriculum of the training system emphasizes on facing project, industry oriented requirements, basing on the needs of enterprises, strengthen the research production technology and management innovation ability training. But in China, the society of professional degree of talent training target positioning in the advanced application of innovative talents, the professional degree of talent training programs and academic research has no substantial difference [4]. It is no obvious advantage application skills between professional degree postgraduate and academic postgraduate degree, however, there have weaknesses existed in the basic knowledge and research and innovation capacity.

Engineering colleges and universities of professional degree graduate student talent training system has the following deficiencies: (1) Full-time professional degree graduate training program is basically the same as academic postgraduate training program. The Full-time professional degree graduate training program do not well in training engineering innovation ability, but also professional degree postgraduate theoretical foundation less than academic graduate, and it is no advantage hands-on ability and engineering innovation capability; (2) The target and operability of practical teaching system is not strong, professional degree postgraduate one year corporate practice is "blur" which has no specific practical training program, no innovation practice platform and 
no assessment methods in training system; (3) the current training mode is lack of necessary policy support, and the mechanism to cultivate the innovation ability should be improved.

In order to achieve the goal of national innovation driven strategy which strengthen the professional degree of postgraduate students in the development of technology and innovation ability. The research what based on innovation driven ability of professional degree graduate student personnel training system [5]. And what need to strengthen the contacts among the professional practice, curriculum system and the goal of cultivating innovative ability [6]. Therefore, exploring the enterprise and industry organizations who participate in professional degree graduate training system construction, construction of professional degree graduate innovative ability cultivation technology platform and system environment, then building the Professional Degree Postgraduate Creative Ability of technology platforms and institutional environment which provide assurance from human resources, technology, capital, to improve professional practice graduate degree in creative ability, improve the practice of training innovative talents safeguard mechanism has important practical significance.

\section{Based on the Forming Factors of the Innovative Ability of Professional Degree Graduate Student Innovation Ability Training System}

Engineering innovation ability of Professional degree graduate engineering innovation ability mainly as follows: (1) combined with the production practice of technical development ability: including major projects of technical innovation, optimize production processes ,propose new technology, construction technology innovation; (2) management of innovation ability: including the model of project management innovation, project investment and financing management innovation, organization innovation in project management, production process innovation and so; (3) a certain R \& D capabilities to include the proposed engineering structure design method, design and development of new materials, new products, put forward new method and so on.

The main factors of the formation of professional degree postgraduate in engineering innovation ability are obtained through the related research: (1) The basic engineering and technical professional theories. On the basis of specialization during the period of school is the foundation of postgraduate students innovation ability, postgraduate students only grasp engineering structure principle, the process of design theory and engineering and technology should made to the theory as an engineering innovation navigation; (2) technological innovation training. Whether in school or during the work, the basic innovation training is necessary. Generally the postgraduate students in the school that the innovation training time is very little, Participate in the transition period of enterprise innovation projects is relatively long. On the contrary, the more participates in the engineering practice and the technical research and development activities the school, the research foundation and the innovation ability is more strong; (3) The research atmosphere and the innovation policy environment. Enterprises have incentive and innovation policies, as well as a good team of innovation on the formation of professional degree graduate students have a positive role in promoting innovation; (4) The creation of jobs. Postgraduate work in research or technology development department will promote their thinking and technological change, However if in the repeated operation or mechanical working environment, the creative is difficult to play; (5) industry innovation demand push. There are differences between the different demand of industry innovation that the more innovation needs the greater the power of the school and business innovation research and innovation training. these needs provide a good environment for training postgraduate innovation ability, such as the rapid development of rail traffic demand what need technology, operational safety for rail transit technology innovation put forward the new requirements, research institutions, colleges and universities, and manufacturing enterprises through technical innovation has made a lot of new achievements, but also cultivate a number of innovative talents.

Combination of postgraduate students innovation ability forming factors and that the cultivation of training the professional degree postgraduate engineering innovation ability must be in engineering and technical training as a platform, as well as incenting enterprises, experts and industry organizations participate in the professional degree postgraduate courses reform and 
construction. And develops the development of industry characteristics of the innovation of curriculum resources what make the enterprise technology innovation and management problems as the subject material to school-enterprise cooperation in postgraduate students training system normalization. Therefore, we must establish a Postgraduate Degree Engineering Innovation Competency Training System:

(1) A good creative talent policy and institutional system. Training innovation talents is an important guarantee for building innovation-oriented country, "to deepen the reform of postgraduate education of opinions" (Teaching and Research 2013) proposed the establishment of the 1st to enhance professional competence oriented professional degree postgraduate training model, to train professional with innovative, and practical ability Master's degree what is required for students to enhance the knowledge, ability and quality of all aspects of the Higher Education sectors. Basic knowledge mainly comes from the theory of classroom teaching; knowledge transfer ability and practical innovation ability need to be acquired through professional practice in enterprise base. In order to realize the innovative talents training target, the country needs introduction of business and industry to support graduate students training incentive mechanism and policy system, education management departments establish innovative talents training system and evaluation system, implement the cultivation of innovative talents of teachers and ensure funding for training.

(2) Enterprises have systematic innovation training platform and management system. Innovation platform construction is the important way of cultivating the ability of professional degree postgraduate in engineering innovation which based on a certain types of professional and industry to establish innovative training platform which as the implementation of "industry innovation training project" organization., and what made both the new innovative training system conform to the requirements of the teaching, and convenient to make enterprise organization innovation training and examination. Over the years, locking of industry innovation training course resources and innovation training courses cannot be integrated into the teaching plan, that cased the professional degree postgraduate student innovation ability training to become a castle in the air.

(3) The school training program should include the "industry innovation training project" and the system of post graduate curriculum resources. it is a necessary path of the development of the innovative national strategy that is organized, large-scale trained engineering innovative talents. Taking enterprise 's new technology and innovation working methods training program, use into training students in technology development process of enterprise, it attracts industry to invest the postgraduate students' innovative ability in education, promotes the professional degree education employment and engineering innovation capability as a guide for innovation-oriented training project development and Curriculum Reform.

(4)There are perfect double-qualified instructors choice system and incentives system. The tutor has the basic scientific research ability at the same time has the enterprise practice experience, and can undertake the enterprises' horizontal topic, Seemly the tutor of enterprise should have a certain number of application type scientific research achievements. we can set up a training system what for cultivating the tutor of professional degree postgraduate, in which needs the tutors participate in the construction of enterprise practice platform and management system, at the same time, has to calculate and assess the tutors' workload in enterprise. All of these will be as the title assess incentive conditions for a tutor. And the enterprise mentor to guide professional degree graduate as promotion is the title of the selection criteria.

\section{The Path of Achieving Engineering Postgraduates' Innovative Ability Training System}

To build a professional degree graduate student innovation ability training system which combining the training target and innovation ability requirement of professional degree graduate, deeply surveying enterprise, industry and analyzing the association factors that are the formation of professional degree postgraduate innovation ability, as well knowing of professional degree graduate student innovation ability demand, current situation and existing problems. To discuss the system and mechanism of the joint guidance of school supervisors, enterprises and industry experts. then help to form innovative talents "training production line" what organics combination of the 
theory and practice, and what complementary advantages of enterprises universities researches cooperation.At the same time, the establishment of a guarantee mechanism which connected school ,enterprise and scientific research and units-government departments cooperation training innovative talents, funds and policy, to strong capability in engineering and innovation specific high-level specialized personnel training.

(1)To define the orientation of talent cultivation of full-time professional degree graduate students in Engineering Colleges. According to the target of talent training and social demand, it is clear that the professional degree graduate students in engineering colleges located: training innovation talents in engineering field and compound types high-level engineering and technical talents. Such talent is to host a large and complex project what needs to analysis or design, and to solve the key technical problems what occurs in major engineering construction and project management; as well as to carry out large-scale engineering detection, assessment and analyzing or processing project accidents; to make a organization major strategic decision and management decision through application of modern management and decision making technology.

(2) To explore the influence factors and formation mechanism of the innovation ability of professional degree in innovation of engineering. Through the investigation of postgraduates' working conditions and their engineering innovation ability. By investigating the related enterprises how to evaluate the engineering innovation ability of professional degree graduate students in engineering. Schools and enterprises need to jointly explore the innovation ability evaluation index system what is use for accessing professional degree graduates' innovation ability. And combination of talent training program, cultivating mode and training effect for furtherly analyzing the influencing factors of innovation ability in engineering, And then researching the innovation ability condition and the mechanism of formation, exploration of the effective way of engineering innovation ability, from all of this, these laid the theoretical basis for the improvement of training systems and professional degree students practice teaching system.

(3) To construct the system of professional degree graduate talents training based on the ability of engineering innovation. According to the influential factors of engineering innovation ability of professional degree graduate students, explore the ways and methods to improve personnel training, build a scientific and rational engineering creative talent training system. According to the professional degree graduate program of excellence ideas to build atheory curriculum system for professional degree graduate student and the practice teaching system of innovation ability, improve the professional practice of innovation and "enterprise innovation course" credits, research the path of talents training mode and construction of innovation platform.

(4) To establish the "three main bodies" and "three stages" innovation training project selection system based on the innovation ability. Professional degree graduate students innovative ability training methods include: graduate students to participate in instructors' scientific research topic, participate in enterprise technology development platform or enterprise engineering innovation practice and writing part of the research papers. Therefore, it is necessary to establish corresponding "body of training" and "steps of training". Among the three bodies included: school classroom, School enterprise tutor and enterprise school supervisor through curriculum and teaching in university is to build a professional theoretical foundation. School enterprise tutor training basic professional ability, and basic of research ability. At the same time, business school teacher training engineering innovative and comprehensive ability. Three stages, including construction of basic theory, professional ability and research methods, comprehensive training the engineering innovation of enterprise. At every step that completing the targets of learning contents and cultivating innovation ability in training stages, and reflecting the thicker engineering, theoretical basis and strong engineering innovation ability cultivation system, as shown in Table 1.

Professional degree graduate engineering innovation training programs include: in design unit design formulation, in complex structure calculation and analysis, to participate in the expression of the specification for the design and application of; take part in the research and development of key technologies in enterprises and engineering research, Key technology control of quality safety in production process; to participate in the professional testing organizations or industrial and mining 
enterprises detection technology development, Calculation analysis and evaluation of engineering quality data; to participate in the financial and operating condition diagnosis, evaluation and making decision of major business or studying monographic technical problems.

Table 1 The content of training system about the three main bodies and the three stages of engineering innovation ability

\begin{tabular}{|l|l|l|l|}
\hline $\begin{array}{l}\text { three main } \\
\text { bodies }\end{array}$ & three stages & content & Target \\
\hline school lessons & $\begin{array}{l}\text { construction of } \\
\text { basic theory }\end{array}$ & $\begin{array}{l}\text { Engineering Foundation、 } \\
\text { Engineering Mathematics }\end{array}$ & $\begin{array}{l}\text { Basic knowledge, basic } \\
\text { theory and basic literacy }\end{array}$ \\
\hline $\begin{array}{l}\text { School } \\
\text { enterprise tutor }\end{array}$ & $\begin{array}{l}\text { professional ability、analysis, } \\
\text { Research method }\end{array}$ & $\begin{array}{l}\text { Professional advanced } \\
\text { courses, professional } \\
\text { practice }\end{array}$ & $\begin{array}{l}\text { Technical } \\
\text { engineering practice ability } \\
\text { training }\end{array}$ \\
\hline $\begin{array}{l}\text { enterprise } \\
\text { school } \\
\text { supervisor }\end{array}$ & $\begin{array}{l}\text { Enterprise } \\
\text { innovation training } \\
\text { project }\end{array}$ & $\begin{array}{l}\text { Participate in engineering } \\
\text { design, project } \\
\text { management }\end{array}$ & $\begin{array}{l}\text { Research reports and thesis } \\
\text { to solve engineering } \\
\text { problems }\end{array}$ \\
\hline
\end{tabular}

\section{The Safeguard Mechanism for the Implementation of Professional Degree Research Engineering Innovation Ability Training System}

The Supporting Policy of Safeguard Mechanism. Including: (1)Regulation of preferential tax policy. Encourage enterprises to provide professional degree graduate training program. That is to say enterprises set up innovation training fund for graduate student and countries give preferential tax to those enterprises according to its offer of graduate student innovation training personnel and expense situation. (2) Giving priority in the field of business or moderate tilt of market access to those enterprises who participate in the training of innovation. Putting the innovation training performance which is given by enterprises to graduate into the enterprise prestige points. And making the effective enterprises of production-study-research cooperation get preferential access to engineering contracting, engineering consulting, technology development, etc. (3)The tilt policy of professional title evaluation for academic supervisor. Giving professional title evaluation tilt to enterprises supervisors who guide innovation training. Confirming the enterprises' innovation training achievements which made by tutors. Or setting up the "engineering applied" title when evaluate professional title. (4)Exploring the safety management responsibility system of production-study-research cooperation, regulating innovative practice insurance system. Students, schools, enterprises and the third part jointly invest to build innovative practice insurance fund and the relevant insurance pay of professional degree graduate. And clearly define the responsibility of the parties in the graduate innovation practice. (5) Establishing innovative training platform and training evaluation system. Including supervisors' workload confirmation system and their guidance results' registration and evaluation system; Knowing the quantity of innovation training credits and evaluation methods of professional degree graduate student, establishing the system of innovation research results and credit approval and so on.

Organization and Talent Safeguard Mechanism. (1)The competent departments of education establish graduate student innovation training management organization and the corresponding management system. (2) Building cooperation mechanism between enterprise and school organization. Including regular communication system, preparation of innovation training plan, implementation of innovation training funds and security system. (3)The implementation of human resource safeguard mechanism of school and enterprise. Human resources safeguard mechanism includes the "double type" teachers training system of enterprise and school, carrying out entry conditions of enterprise mentors, and performance evaluation and incentive system, etc.

Innovative the Safeguard Mechanism of Project Funds and Practice Sites. (1) Multi-raising innovation training funds and strengthening the management of it. Establish the system of 
innovation training and funding sources and management for graduate students, raise professional degree graduate innovation training funds jointly based on the School internship funds, Enterprise innovation training special funds, The donation funds of Nonprofit Organizations and Government funds. Carry out salary system for school and enterprise mentors, strengthening the management of laboratory construction funds and earnings by school enterprise cooperative, standardizing the management of practice insurance fee. (2)Implement innovation training programs and places. The innovation project and technology development platform as the access conditions for enterprises. Government introduced preferential policies for enterprises to cultivate graduate student or pledged financial support, established security mechanism for professional degree graduate participating in enterprise innovation practice.

Quality Supervision Evaluation and Incentive Mechanism. (1)Supervision and evaluation mechanism. Establish innovation training effect evaluation and supervision system arounding the engineering innovation ability, carry out the evaluation adaptability to the teachers of innovation base and programs of innovation training, evaluate the process management for graduate student participating in innovation training. Establish the evaluation system of engineering innovation training achievement. And the government evaluate the quality of joint training of enterprise and school. (2) Excitation mechanism. Industry associations give the effectiveness of a significant corporate spirit award, give a slant on market access; While, cancel innovation training platform or relevant preferential policies for the enterprises with bad effects. And give a tilt to the effectiveness school in the number of students or increase the funds for the construction of innovation training platform; While cancel the title of "innovation training laboratory" or return to construction funds. In addition, establish the corresponding reward and punishment system for the mentors whose guiding effect are obvious.

\section{Summary}

To the inefficiency of the basic knowledge and the ability of engineering practice recreation of professional degree postgraduate, The article raise up suggestions of the engineer creation ability training system based on the developing goal of professional postgraduate, and clear and definite the direction of it; the article observe that on the basis of analyzing the factors and the formation mechanism of engineering recreation ability to set up the "3 subjects ""3 steps "recreation training system based on the recreation ability and the security system of the professional degrees research engineering recreation ability; and carryout the institution of school and company supervisors or team super in order to establish an organization of recreation ability training and the talents security system and the long-term mechanism of postgraduates recreation practice with policy and fund guarantee ; and strength the system of recreation training supervision and administration, etc. these suggestions will support as education administration authority's decision making for the professional degrees research.

\section{Acknowledgement}

Fund project: chongqing education scientific planning project (2014 -GX -031); Graduate education reform project in chongqing (yjg153049).

\section{References}

[1] Z. Yang: A Comparative Study on the Training Mode of Professional Master Degree Students at Home and Abroad [J]. Journal of educational science of Hunan Normal University, 2013(2):93-97.

[2] Y. Zhang and R.W. He. Innovative Research on the Training Mode of Full-time Professional Degree Master of Local Engineering Colleges [J]. Higher education exploration, 2013(5):123-126.

[3] W.L. Xu, Y.Y. Kong and M.E. Li: The Training Mode of Professional Degree Graduate 
Students is "Spiral Upgrade" $[\mathrm{J}]$.The research of Higher Engineering Education, 2011(2):149-154.

[4] C.Y. Qian: Analysis on the Obstacles and Countermeasures of the Cultivation of Innovation Ability of Graduate Students [J]. Higher education exploration, 2004(1):52-53+87.

[5] G.H. Wen: Pay Special Attention to the Professional Practice, to Ensure the Quality of Graduate Education in Professional Degree [J]. Degree and graduate education, 2010(8):1-4.

[6] P.L. Zhang, C.C. Fu and M. Zhu: Independent and Practical Problems of the Curriculum System of Full-time Master's Degree in Postgraduate Education[J].Research on Higher Engineering Education, 2015(1):161-167. 